\title{
Investigating the Perceived Comparison of Work from Office vs. Work from Home during Covid-19: An Empirical Study
}

\author{
Jean Rouh ${ }^{1}$, Serene Dalati ${ }^{2 *}$, Marah Al Bich ${ }^{3}$ \\ ${ }^{1,2,3}$ Management Department, Faculty of Business Administration, Arab \\ International University, Syrian Arab Republic \\ ${ }^{2}$ s-dalati@aiu.edu.sy
}

\begin{abstract}
This research investigates perceived comparison of work from office vs. work from home in work location, outcomes and examine the important of home arrangements needed for work from home. The research methodology analyzes 205 different employees' respondents by distributing questionnaire on telecommunication organizations in Syria (Syriatel, MTN, and View Internet). There is no significant difference in perceived comparison of work location (i.e., work from home with work from office), work location doesn't really matter for employees. Although there is a significant difference in the perceived comparison of work outcomes (i.e., work from home with work from office), employees' outcomes are better while working at home. Also, we determined the important home arrangements for employees who are working or might work from home.
\end{abstract}

Keywords: WFH(work from home), WFO (work from office), telecommunication sector, ICT, work location, work outcomes 


\section{Introduction}

At the beginning of 2020 and because of the lockdown caused by COVID 19 "work-from-home" has been a needful action for many companies and organizations. Societies have faced an unexpected forced situation where organizations and companies have continued to work virtually while their workers are separated at their homes, with the needed technology also with conditions of digital and legal security. This new situation would have the possibility of serious effect on all kinds of businesses, even if they had tried to work virtually before on not (OECD, 2020). However, working from home allowed some organizations and employees to face this challenge well, especially those who used to work virtually before. Capability to work from home during the pandemic was not able to all, and that caused inequality to increase. For example, during the lockdown, many employees who worked with the minimum wage in works required site presence (Brussevich, Dabla-Norris, and Khalid, 2020).

Work from home using information and communication technologies (ICTs) idea originated in California USA in the seventies of the last century (Nilles 1975) and was developed by companies based there such as Yahoo in the eighties using the term telecommuting, which was known later as telework. Three decades later, markets have become flooded with cheaper, smaller, and increasingly connected devices, such as tablet computers and smartphones, accompanied by a vast dispersion of the World Wide Web and the Internet. These devices now allow employees to stay connected with each other at any time from any place.

Yet as big numbers of employees are forced to work virtually, many faces fundamental issues difficulties like a shortage of space in their home to work virtually. For instance, workers who are not living alone face more challenges than those living on their own because they need to intrude into others' space. Understanding the impact in the long-range of virtual work at the organizations' level and aggregate outcomes is very important because of the increased future potential to work remotely worldwide.

This study investigates the perceived comparison of work from office vs. work from home from the telecommunication sector's occupational staff in Syria's point of view. It is necessary to consider staff evaluation for the forced experiment they faced during the Covid19 crisis in terms of work location and work outcomes. This importance comes to help companies develop strategies to face similar situations if they happen in the future. To that end, it briefly reviews a perceived comparison of work from office vs. work from home in terms of work location and outcomes and discusses the important home arrangements needed to work from home.

\section{Literature Review}

Comparison of work location: work from home vs work from office. According to Tagliro and Migliore (2021), the Italian real estate company's employees embraced 
the extent of change. The authors say that working from home was a disturbing experience when the traditional office working hours turned into work from home due to Covid 19 pandemic. However, as a strategy of adaptation, staff did their best to work at homes in similar way of working from the office. Employees said that a separated room is a necessary need to work throughout work from home. Based on the study outcomes, this conduct is similar to work from office environment before turned into work from home; they would occasionally use other rooms like meeting rooms or other rooms. Furthermore, few employees expressed that sharing room with others is distributing. The reality could describe this that staff are usually used in a shared room with other colleagues in their office. Almost $79 \%$ of their staff preferred to work in office's workstations. Although, all that will be more difficult "privacy wise" while they share the room with children and conceivable while sharing the space with adults.

Beaudoin, Georgules, and Raicht's (2020) study shows that many employees can work at home independently. Still, real productivity and creativity need a team physically present in the same room to solve problems. The study specialized in the following professions; engineering, computing, and design, teams are needed to solve problems a single person would not.

Giurge and Bohns' (2020) study explain the circumstances of transfer to work from home (WFH) and how to avoid common mistakes and failures. The authors say that the current circumstances may not allow employees to keep boundaries between their personal lives and work. Most educational institutions have been sealed, putting more charges on working parents, especially those with limited income. In addition, Organizations are likely to have some difficulties supporting workers who have difficulties sharing spaces with their families while working from home. Even those organizations that already encourage employees to work from home. In addition, here, the author advises employees who have transferred to WFH to try to maintain some boundaries like Putting on work clothes every morning, of course, taking into consideration and before starting to work to replace everyday transportation with a walk around the block or any place. There are workers who created some plans to adapt and keep their everyday working habits. The author continues by saying that working from home seems to be a good transfer for a short period, especially when it comes to everyday transportation to go to the office and to be relaxed at home in a comfortable atmosphere.

Comparison of outcomes: work from home vs work from office. The study by Tagliaro and Migliore (2021) explored the effects of the Covid-19 on work habits and outcomes of working from home during Covid 19 vs office-working. The result of the study indicates that the quality of the individual and teamwork has improved. Because of increasing concentration, holding online meetings, a phone call to share projects and information at home. Also, optimization in commuting routes might have contributed to perceived improvement in productivity with WFH and wasting 
time, increasing stress in WFO also females have a higher score than males with balancing their personal and working lives, and negative impact for workers with children, WFO better in occasions to socialize than WFH.

Research by Bloom, Liang, Roberts, Ying (2013) was based on a randomized surveying 16,000 workers of, NASDAQ-listed Chinese travel agency. The organization's call center staff were randomly assigned to work either from home or in the office for almost one year. The study outcomes show performance increase while working from home by $13 \%$, of which $9 \%$ came from working more time per shift, and $4 \%$ came from more calls per unit of time. That was an incentive for the company to offer their staff the option of switching to work from home and allowing the employees to reselect working location and choose between work from the office and working from home. Interestingly, over half of employees chose, which led to the initial WFH gains to almost double to $22 \%$.

A research study by Dockery and Bawa (2014) explored whether WFH is bad or good. The result from Australian evidence showed that staff who work from home are more satisfied, especially with the balance between their work and private life. Furthermore, men who work from home have higher overall job satisfaction. Although for those, who do so through a formal agreement and who work part-time work from home have a positive effect on them. We conclude that the option to work from home is a positive job attribute for any given level of hours worked.

Lovich et al. (2020) explored employees' opinion in Remote Work. They examined more than 12,000 professional workers before and during COVID-19 in India and Germany's united states. Results signify that $75 \%$ of respondents' results conducted that they were able to maintain or improve productivity at the beginning of the pandemic. Examples are analyzing data, writing presentations, and executing administrative tasks. But on tasks that need collaboration with colleagues, teamwork, or customer interaction. Although, 51\% and more of all employees responded that for tasks that need collaboration, they could improve or maintain their productivity. Whether working virtually or traditionally, the study shows that four factors correlate with employee perceptions of their productivity on collaborative tasks: social connectivity, mental health, physical health, and workplace tools, $79 \%$ of employees are satisfied doing better on all four of these factors said they have been able to maintain or improve productivity on collaborative tasks.

Rozman and Tominc's (2021) study shows the impact of emotional, behavioral and physical and symptoms of health problems between staff before and during the pandemic in many companies in Slovenia. The results of this study show statistically significant differences in emotional, behavioural and physical and symptoms of health problems between staff before and during the pandemic are intensified compared to the previous traditional work before the pandemic.

Work from home arrangements. A Study by Routley (2020) explored results by 6 
different dimensions. Each and every one describes a variable that happened because of the pandemic. To summarize charts, we can say that a flexible schedule, the ability to work from any location, and no more commuting were the top reported benefits. There are some challenges people face as they work remotely, loneliness, unplugging after work, lack of collaboration and communication, reliable home technologies and facilities, distraction at home, lack of motivation.

The research by Kniffin (2021) discussed the differences between WFH and WFO before and after the pandemic, especially from a management perspective, so the author says that many employees are turned into working from home coercively affected by the Covid-19. The majority had fundamental difficulties like not having enough space in one room to work at their home. For example, workers sharing rooms in their homes with others have more difficulties than workers who are not. Moreover, workers have problems balancing work and private life.

\section{Research Methodology}

The problem of this research compares the differences of work from office vs. work from home in terms of location and outcomes. Also, it presents the home arrangements that are important to the employees in case they are working from home during the Covid-19. Almost all societies have faced this problem, so we decided to study Syrian society and focus on the service sectors. Research hypotheses are:

H1. There is a significant difference in perceived comparison of work location (i.e., work from home with work from the office) among staff in telecommunication organizations in Syria.

$\mathrm{H} 2$. There is a significant difference in perceived comparison of work outcomes (i.e., work from home with work from office) among staff in telecommunication organizations in Syria.

Research methodology refers to the practical "how" of any given piece of research. More specifically, it's about how a researcher systematically designs a study to ensure valid and reliable results that address the research aims and objectives. The methodology justifies the design choices by showing that the chosen methods and techniques fit the research aims and objectives and will provide valid and reliable results. A suitable research methodology provides scientifically sound findings, whereas a poor does not. Figure 1 illustrates the research process.

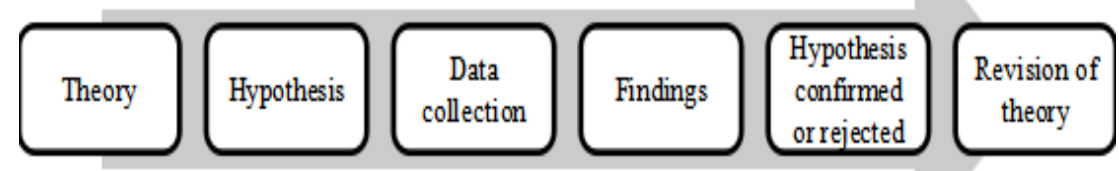


Fig. 1: The process of deduction methods steps

A deduction is a form of argument that purports to be conclusive - the conclusion must necessarily follow from the reasons given. These reasons are said to imply the conclusion and represent proof. This is a much stronger and different bond between reasons and conclusions than with induction (Cooper and Schindler 2013). Deductive reasoning is the logical process of deriving a conclusion about a specific instance based on a known general premise or something known to be true. For example, while you might occasionally have doubts, we know that all business professors are human beings. If we also know that Barry Babin is a business professor, we can deduce that Barry Babin is a human being (42 Zikmund, hypothesis).

Table 1: Research Hypotheses

\begin{tabular}{|c|c|c|}
\hline No. & Statement & Test \\
\hline H1 & $\begin{array}{c}\text { There is a significant difference in perceived comparison of } \\
\text { work location (i.e., work from home with work from the office) } \\
\text { among staff in telecommunication organizations in Syria }\end{array}$ & $\begin{array}{c}\text { One sample } \\
\text { T test }\end{array}$ \\
\hline H2 & $\begin{array}{c}\text { There is a significant difference in perceived comparison of } \\
\text { work outcomes (i.e., work from home with work from the } \\
\text { office) among staff in telecommunication organizations in } \\
\text { Syria. }\end{array}$ & $\begin{array}{c}\text { One sample } \\
\text { T test }\end{array}$ \\
\hline
\end{tabular}

Sampling design. Sampling is a technique of selecting individual members or a subset of the population to make statistical inferences and estimate the population's characteristics. Different sampling methods are widely used by researchers in market research so that they do not need to research the entire population to collect actionable insights. The Sampling design of this research is non-probability sampling. We choose members for this research from big telecommunication companies in Syria, and our segment is functional staff and management level.

Questionnaire design. The questionnaire contained four sections.

Table 2: first section personal profile

1. Name of the company

2. Department

3. Age (in numbers)

4. Gender: Male $\square$ Female $\square$

5. Marital Status: Single $\square$ Married $\square$

6. Do you have children: Yes $\square$ Nor 
7. Education Level: Other $\square$ Bachelor $\square$ Master $\square \mathrm{PhD} \square$

8. Position: Top-level manager $\square$ Midlevel manager $\square$ Supervisor $\square$ Functional Staff $\square$

9. Work experience in an existing company (in numbers)

Measures and scale. This research comprises four sections. The first section is a personal profile containing the personal profile where questions have different data properties, including nominal scale (name of the company, department, gender, marital status, education level, and position). Also, the personal profile includes a ratio scale (age of respondent and work experience).

Table 3: Second section comparison in work location "WFH vs. WFO"

\begin{tabular}{|l|}
\hline 10. The suitability of the space \\
\hline 11. Individual privacy \\
\hline 12. Suitability of indoor environment \\
\hline 13. External view \\
\hline 14. Individual space and absence of distractions \\
\hline 15. Interaction with colleagues and the presence of spaces for interactions \\
\hline 16. available storage for own items/work items \\
\hline 17. Better ICT facilities \\
\hline
\end{tabular}

Table 4: Third section comparison in outcomes, "WFH vs. WFO"

18. Individual work productivity

19. Team productivity

20. Working hours

21. Concentration on tasks

22. Work-life balance

23. Socialization and occasion

24. Possibility to take a break

25. Physical health

26. Psychological health

Table 5: The fourth section contained the work from home arrangements

1. Independent workroom to limit interaction with other people

2. Good lighting to reduce visual fatigue

3. High-speed internet

4. ICT tools (camera, headphones, etc.)

5. Office table

6. Printer

7. Laptop 
8. Projector

9. Scanner

10. Video conferencing applications (Zoom, Skype, big blue button)

The second section of the questionnaire comprises a perceived comparison of work location "work from home compared to work from the office," where comparative scale is employed. This section applies a five-point comparative scale to measure respondents' perception of comparing work location specifically work from office versus work from home. On this scale, 1 indicates that the respondent's experience is extremely worse at home, and 5 indicates that the respondent's experience is extremely better at home. The subscale consists of 8 items.

The third section of the questionnaire comprises a comparison about Perceived comparison of work Outcomes "work from home compared to work form office", where comparative scale is employed. This section applies a five-point comparative scale to measure respondents' perception of comparing work location specifically work from office versus work from home. On this scale, 1 indicates that the respondent's experience is extremely worse at home, and 5 indicates that the respondent's experience is extremely better at home. The subscale consists 9 items.

In the fourth section of the questionnaire, we used the Likert scale to measure the importance of working from home. In this section, a five-point Likert scale was applied 1 indicates that the respondent's experience is totally unimportant, and 5 indicates that respondent experience is totally important. The subscale consists of 10 items.

The questionnaire has been translated from English to Arabic to be easier for people with weak English. This process lets people understand the questionnaire in a better way and gives us more reliable answers. The questionnaire was translated from English to Arabic. Consequently, the senior project supervisor reviewed it and authorized to proceed with data collection.

\section{Research Analysis}

Demographic analysis. Descriptive data examines the sample characteristics and respondents' demographic profiles. The demographic profile includes respondents' company names, department, age, work experience, gender, marital status, parental status, education level, and position. Descriptive data indicates that the targeted sample is from different telecommunication companies as follows $81 \%$ from Syriatel, $16.1 \%$ from MTN, 2.9\% from View internet. Respondents were from many departments $1.5 \%$ from the Call centre department, $4.9 \%$ Customer service, $31.2 \%$ Site operation, 2.4\% Finance, $7.8 \%$ HR, 14.1\% IT, 1.5\% Marketing, 6.3\% Network, $0.5 \%$ Sales and $29.8 \%$ from other departments. Respondent's average age is 34.25 years; work experience in the current telecommunication companies is 7.63 years. 
Descriptive data illustrates that $70.2 \%$ of the sample study are male, $29.8 \%$ female, $48.8 \%$ are single, and 51.2 are married, $45.4 \%$ have children, $54.6 \%$ don't have children, $70.2 \%$ have a bachelor's degree, $18.5 \%$ master's degrees, and $0.5 \%$ $\mathrm{PhDs}$ and $10.7 \%$ for others education levels, their administration position is $3.9 \%$ are management level, 96.1 are functional staff.

Table 6: Name of Companies (n 205)

\begin{tabular}{|c|c|c|}
\hline Name of Companies & Frequency & Percent (\%) \\
\hline Syriatel & 166 & 81.0 \\
\hline MTN & 33 & 16.1 \\
\hline View Internet & 6 & 2.9 \\
\hline Total & 205 & 100.0 \\
\hline
\end{tabular}

Table 7: Department (n 205)

\begin{tabular}{|c|c|c|}
\hline Department & Frequency & Percent (\%) \\
\hline Call center & 3 & 1.5 \\
\hline Customer service & 10 & 4.9 \\
\hline Site operation & 64 & 31.2 \\
\hline Finance & 5 & 2.4 \\
\hline HR & 16 & 7.8 \\
\hline IT & 29 & 14.1 \\
\hline Marketing & 3 & 1.5 \\
\hline Network & 13 & 6.3 \\
\hline Sales & 1 & 0.5 \\
\hline Other & 61 & 29.8 \\
\hline Total & 205 & 100.0 \\
\hline
\end{tabular}

Table 8: Demographic profile (n 205)

\begin{tabular}{|c|c|c|c|}
\hline demographic profile & N & M & SD \\
\hline Age & 205 & 34.25 & 8.087 \\
\hline Work Experience & 205 & 7.63 & 5.733 \\
\hline
\end{tabular}

Table 9: Gender (n 205)

\begin{tabular}{|c|c|c|}
\hline Gender & Frequency & Percent $(\boldsymbol{\%})$ \\
\hline Male & 144 & 70.2 \\
\hline Female & 61 & 29.8 \\
\hline Total & 205 & 100.0 \\
\hline
\end{tabular}


Table 10: Marital status (n 205)

\begin{tabular}{|c|c|c|}
\hline Marital status & Frequency & Percent (\%) \\
\hline Single & 100 & 48.8 \\
\hline Married & 105 & 51.2 \\
\hline Total & 205 & 100.0 \\
\hline
\end{tabular}

Table 11: Parental status (n 205)

\begin{tabular}{|c|c|c|}
\hline Code Name & Frequency & Percent $(\boldsymbol{\%})$ \\
\hline Yes & 93 & 45.4 \\
\hline No & 112 & 54.6 \\
\hline Total & 205 & 100.0 \\
\hline
\end{tabular}

Table 12: Education Level (n 205)

\begin{tabular}{|c|c|c|}
\hline Education Level & Frequency & Percent (\%) \\
\hline Bachelor & 144 & 70.2 \\
\hline Master & 38 & 18.5 \\
\hline PhD & 1 & 0.5 \\
\hline Other & 22 & 10.7 \\
\hline Total & 205 & 100.0 \\
\hline
\end{tabular}

Table 13: Position (n 205)

\begin{tabular}{|c|c|c|}
\hline Position & Frequency & Percent (\%) \\
\hline Top level management & 8 & 3.9 \\
\hline Functional Staff & 197 & 96.1 \\
\hline Total & 205 & 100.0 \\
\hline
\end{tabular}

Reliability analysis. Cronbach alpha analysis is conducted to measure the internal reliability of items in the two sections to know if there is consistency between them or not. The acceptable levels of reliability are 0.70 and more. Therefore, there is consistency between items. If the value was smaller than 0.70 , there is weak reliability and less acceptable, and therefore there is no consistency between items. Cronbach alpha analysis was applied on a pilot test, comprising 50 cases from the target organizations (Syriatel, MTN, View internet). As for the first variable, the "comparison of work locations" alpha value is 0.83 . As for the second variable, the "comparison of work outcomes" alpha value is 0.87 , and these two values indicate excellent reliability. 
Table 14: Reliability analysis $(\mathrm{n}=50)$

\begin{tabular}{|c|c|c|}
\hline Variable Component & Number of Items & $\begin{array}{c}\text { Alpha ( } \boldsymbol{\alpha}) \text { without } \\
\text { deleting any items }\end{array}$ \\
\hline Perceived comparison of work location & 8 & 0.83 \\
\hline Perceived comparison of work outcomes & 9 & 0.87 \\
\hline
\end{tabular}

Descriptive analysis. Descriptive statistics illustrate 3 sections, namely comparison of work location (work from home vs work from the office), work outcomes (work from home vs. work from the office), and work from home arrangements. Tables 13, 14, and 15 illustrate means scores and standard deviation for the mentioned sections.

Table 15: Descriptive analysis of work comparison work location $(n=205)$

\begin{tabular}{|rl|c|c|}
\hline \multicolumn{2}{|l|}{ Perceived comparison of work location } & Mean & SD \\
\hline 1. & The suitability of the space & 3.23 & 1.116 \\
\hline 2. $\quad$ Individual privacy & 3.53 & 1.127 \\
\hline 3. $\quad$ Suitability of indoor environment & 2.30 & 1.246 \\
\hline 4. $\quad$ External view & 3.28 & 1.154 \\
\hline 5. Individual space and absence of distractions & 3.07 & 1.212 \\
\hline 6. $\quad \begin{array}{l}\text { Interaction with colleagues and the presence } \\
\text { of spaces for interactions }\end{array}$ & 2.43 & 1.108 \\
\hline 7. & Available storage for own items/work items & 3.12 & 1.087 \\
\hline 8. $\quad$ Better ICT facilities & 2.62 & 1.189 \\
\hline
\end{tabular}

Descriptive analysis of work comparison work location (work from home vs. work from the office) was applied on 205 cases from the target organizations (Syriatel, MTN, View internet). It determines that the mean is out of 5. The suitability of the space was 3.23 and individual privacy with a mean of 3,53 external view with mean of 3.28 , individual space and absence of distractions with mean of 3.07, and available storage for own items/work items with a mean of 3,12, which is better at home. Suitability of indoor environment with 2.30 mean, interaction with colleagues and the presence of spaces for interactions with mean of 2.43 and better ICT facilities with mean of 2.62 which they are worst at home.

Table 16: Descriptive analysis of work comparison work outcomes $(n=205)$

\begin{tabular}{|c|c|c|}
\hline Perceived Comparison of Work Outcomes & Mean & Std. Deviation \\
\hline 9. Individual work productivity & 3.34 & 1.005 \\
\hline 10. Team productivity & 2.77 & 1.064 \\
\hline 11. Working hours & 3.46 & 1.157 \\
\hline 12. Concentration on tasks & 3.20 & .996 \\
\hline 13. Work-life balance & 3.19 & 1.132 \\
\hline
\end{tabular}




\begin{tabular}{|l|l|l|}
\hline 14. Socialization and occasion & 3.15 & 1.075 \\
\hline 15. Possibility to take a break & 3.77 & 1.036 \\
\hline 16. Physical health & 3.78 & 1.064 \\
\hline 17. Psychological health & 3.63 & 1.115 \\
\hline
\end{tabular}

Descriptive analysis of work comparison work outcomes (work from home vs. work from the office) was applied on 205 cases from the target organizations (Syriatel, MTN, View internet). It determines that the mean is out of 5, individual work productivity with mean of 3.34, working hours with a mean of 3.46 , concentration on tasks with a mean of 3.20, work-life balance with a mean of 3.19, socialization and occasion with a mean of 3.15 , possibility to take a break with mean of 3.77, physical health with mean of 3.78, psychological health with mean of 3.63 which they are better in-home and the team productivity mean is 2.77 which it is worst at home.

Table 17: Descriptive analysis of work from home arrangements $(n=205)$

\begin{tabular}{|l|c|c|}
\hline Work from home arrangements & Mean & Std. Deviation \\
\hline 1. Independent workroom & 3.8244 & .97939 \\
\hline 2. good lighting & 4.0341 & .93085 \\
\hline 3. High-speed internet & 4.5024 & .77728 \\
\hline 4. ICT tools & 3.7366 & 1.01888 \\
\hline 5. office table & 3.9366 & 1.05295 \\
\hline 6. Printer & 2.8390 & 1.25575 \\
\hline 7. Laptop & 4.6195 & .74860 \\
\hline 8. $\quad$ Projector & 1.9220 & .98705 \\
\hline 9. Scanner & 2.4585 & 1.23847 \\
\hline 10. Video Conferencing applications & 3.4732 & 1.16127 \\
\hline
\end{tabular}

Descriptive analysis of work from home arrangements was applied on 205 cases from the target organizations (Syriatel, MTN, View internet), and it determines that the laptop is almost "totally important" for staff who moved to work from home during the pandemic with mean of 4.6195 out of 5 , then will come the high-speed internet as the second priority with mean of 4.5024 out of 5. Also, it determines that the projector and the scanners are less priority and unnecessary to have during working from home, with a mean of 1.9220 for projector and 2.4585 for the scanner. These results present what staff need for the organization if they face a situation clause to Covid19, which might force their staff to work remotely from home or other places. 


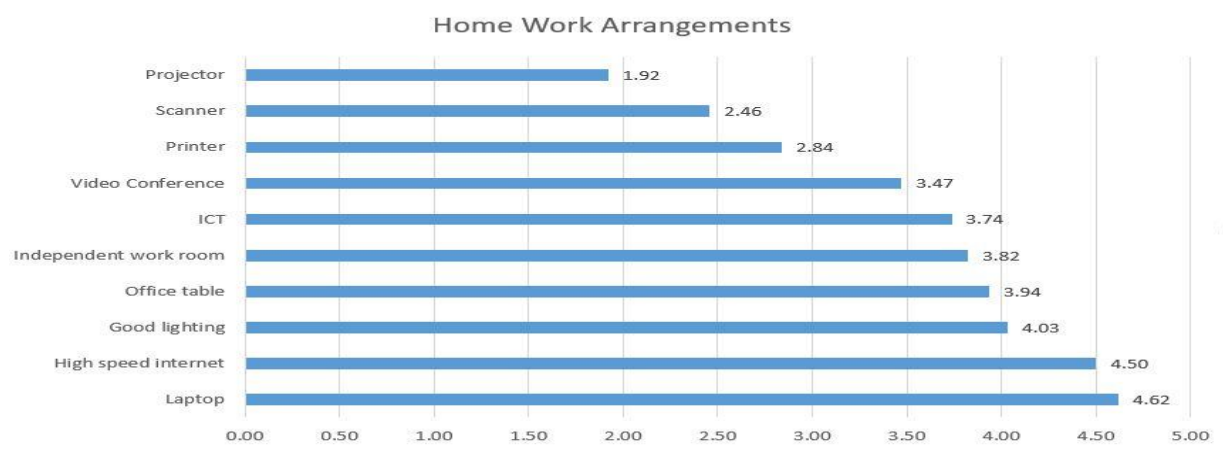

Fig. 2: Homework arrangements.

Normality test. Before testing the research hypotheses, normality tests were performed to determine the selection of the statistical tests performed in this research study. A normality test was performed, examining research variables. Shapiro Wilk test indicates that data is normally distributed were normality test for Perceived Comparison of work locations D $(189)=.987, \mathrm{p}=.071$, normality test for Perceived Comparison Work Outcomes D $(189)=.989, \mathrm{p}=.163$.

Table 18: Normality test

\begin{tabular}{|l|c|c|c|}
\hline \multirow{2}{*}{} & \multicolumn{3}{|c|}{ Shapiro-Wilk } \\
\cline { 2 - 4 } & Statistic & df & Sig. \\
\hline Perceived Comparison of work locations & .987 & 189 & .071 \\
\hline Perceived Comparison Work Outcomes & .989 & 189 & .163 \\
\hline
\end{tabular}

One sample t-test. The first hypothesis in this research investigates perceived comparison in work location between work from office vs. home. To test the first hypothesis, we conducted a one-sample t-test. The result for one sample t-test for work comparison location (work from home vs office): $\mathrm{t}(204)=-0.939, \mathrm{p}=0.349$. This confirms that there is no significant difference in perceived comparison of work location (i.e., work from home with work from the office) among staff in telecommunication organizations in Syria; work location doesn't matter for employees.

The second hypothesis in this research investigates the perceived comparison in work outcomes between work from office vs. home. To test the second hypothesis, we conducted a one-sample t-test. The result for one sample t-test for work comparison work outcomes (work from home vs. work from the office) $\mathrm{t}(204)=$ $6.910, p=0.000$. This confirms a significant difference in perceived comparison of work outcomes (i.e., work from home with work from the office) among staff in telecommunication organizations in Syria; employees' outcomes are better while they are working at home. 
Table 19: One-Sample Statistics - Grand Means

\begin{tabular}{|c|c|c|c|c|}
\hline & N & Mean & $\begin{array}{c}\text { Std. } \\
\text { Deviation }\end{array}$ & $\begin{array}{c}\text { Std. Error } \\
\text { Mean }\end{array}$ \\
\hline $\begin{array}{c}\text { Comparison of work } \\
\text { locations }\end{array}$ & 205 & 2.9476 & .79924 & .05582 \\
\hline Perceived Work Outcomes & 205 & 3.3642 & .75468 & .05271 \\
\hline
\end{tabular}

Table 20: One-Sample t-test

\begin{tabular}{|c|c|c|c|c|c|c|}
\hline & \multicolumn{6}{|c|}{ Test Value $=3$} \\
\hline & \multirow[t]{2}{*}{$\mathbf{t}$} & \multirow[t]{2}{*}{ Df } & \multirow[t]{2}{*}{ Sig. (2-tailed) } & \multirow[t]{2}{*}{$\begin{array}{c}\text { Mean } \\
\text { Difference }\end{array}$} & \multicolumn{2}{|c|}{$\begin{array}{c}\text { 95\% Confidence } \\
\text { Interval of the } \\
\text { Difference }\end{array}$} \\
\hline & & & & & Lower & Upper \\
\hline $\begin{array}{c}\text { Comparison } \\
\text { of work } \\
\text { locations } \\
\end{array}$ & -.939 & 204 & .349 & -.05244 & -.1625 & .0576 \\
\hline $\begin{array}{l}\text { Perceived } \\
\text { Work } \\
\text { Outcomes }\end{array}$ & 6.910 & 204 & .000 & .36423 & .2603 & .4682 \\
\hline
\end{tabular}

Table 21: Hypothesis testing results

\begin{tabular}{|c|c|c|c|}
\hline NO & Statement & Findings & Results \\
\hline $\mathrm{H} 1$ & $\begin{array}{l}\text { There is a significant difference in perceived } \\
\text { comparison of work location (i.e., work from home } \\
\text { with work from the office) among staff in } \\
\text { telecommunication organizations in Syria }\end{array}$ & $\begin{array}{c}\mathrm{t}(204)=- \\
0.939 \mathrm{p}= \\
0.349\end{array}$ & $\begin{array}{l}\text { Hypothesis } \\
\text { rejected }\end{array}$ \\
\hline $\mathrm{H} 2$ & $\begin{array}{l}\text { There is a significant difference in perceived } \\
\text { comparison of work outcomes (i.e., work from } \\
\text { home with work from the office) among staff in } \\
\text { telecommunication organizations in Syria. }\end{array}$ & $\begin{array}{c}\mathrm{t}(204)= \\
6.910 \mathrm{p}= \\
0.000\end{array}$ & $\begin{array}{c}\text { Hypothesis } \\
\text { accepted }\end{array}$ \\
\hline
\end{tabular}

\section{Conclusions}

According to the test that we conducted in this research, on the one hand, we found that the first hypothesis analysis result is not similar to the previous result by Tagliro and Migliore (2021). There is no significant difference in perceived comparison of work location (i.e., work from home with work from the office) among staff in telecommunication organizations in Syria. 
Although some factors in this comparison are really better at home according to the employees' response to the survey, like the suitability of the space, individual privacy, external view, individual space and absence of distractions, and available storage for own items/work items, still, also there were some factors worst at home like suitability of indoor environment interaction with colleagues and the presence of spaces for interactions and better ICT facilities. We believe that they should be taken into consideration. On the other hand, the second hypothesis is similar to the mentioned literature. There is a significant difference in perceived comparison of work location (i.e., work from home with work from the office) among staff in telecommunication organizations in Syria. Also, as mentioned previously, we found essential home arrangements to work from home exactly like the previous results.

Limitation of the study could be related to the methodology used to gather data and select the sample. Although a self-administrated questionnaire is cost-effective and less time-consuming than other methods, response bias is possible (Cooper and Schindler 2011).

The recommendation for future research is to examine larger samples for different sensitive service sectors (Banking and educational). Also, it can explore other geographical locations, not only Syria. It is highly recommended to do a comparison study between genders, parental and marital status to see a clear result what work from home has affected these segments and how, and that would give organizations a good figure how they can support their staff to adopt if they faced same situation in the future.

\section{References}

Bloom, N., Liang, J., Roberts, J., \& Ying, Z. J. (2013). Does Working from Home Work? Evidence from a Chinese Experiment.

Brussevich, M., E. Dabla-Norris, and S. Khalid. (2020). Who will Bear the Brunt of Lockdown Policies? Evidence from Tele-workability Measures Across Countries, IMF Working Paper, No. WP/20/88.

Christian Beaudoin, Julia Georgules, \& Trisha Raicht. (2020). Tenant needs in a post-pandemic world.

Dahik, A., Lovich, D., Kreafle, C., Bailey, A., Kilmann, J., Kennedy, D., Roongta, P., Schuler, F., Tomlin, L., \& Wenstrup, J. (2020). What 12000 Employees Have to Say About the Future of Remote Work.

Dockery, A. M., \& Bawa, S. (2014). Is Working from Home Good Work or Bad Work? Evidence from Australian Employees. In Australian Journal of Labour Economics, 17. 
Donald R Cooper. (2014). Business Research Methods. 12th Edition.

Gorlick, A. (2020). The productivity pitfalls of working from home in the age of COVID-19, Stanford News, <https://news.stanford.edu/2020/03/30/productivitypitfalls-working-home-age-covid-19> (accessed on 17 June 2020).

Jon Carleton. (2019). Telework in the 21st century: an evolutionary perspective.

Kate Lister. (2020). Work-At-Home After Covid 19 Our Forecast. Global Workplace. <https://globalworkplaceanalytics.com/work-at-home-after-covid-19our-forecast $>$

Kniffin, K. M., Narayanan, J., Anseel, F., Antonakis, J., Ashford, S. P., Bakker, A. B., Bamberger, P., Bapuji, H., Bhave, D. P., Choi, V. K., Creary, S. J., Demerouti, E., Flynn, F. J., Gelfand, M. J., Greer, L. L., Johns, G., Kesebir, S., Klein, P. G., Lee, S. Y., ... Vugt, M. van. (2021). COVID-19 and the workplace: Implications, issues, and insights for future research and action. American Psychologist, 76(1), 63-77. <https://doi.org/10.1037/amp0000716>

Mehdi, T., \& Morissette, R. (2021). Catalogue no. 45280001 Working from home: Productivity and preferences StatCan COVID-19: Data to Insights for a Better Canada. <www.statcan.gc.ca>

Morikawa, M. (2020), COVID-19, teleworking, and productivity, VoxEU.org, <https://voxeu.org/article/covid-19-teleworking-and-productivity>

Nick Routley. (2020). 6 charts that show what employers and employees really think about remote working. Visual Capitalist.

Nilles, J.M. (1975). Telecommunications and organizational decentralization, IEEE Transactions on Communications, 23(10), 1142-1147.

OECD. (2020). Supporting people and companies to deal with the COVID-19 virus: Options for an immediate employment and social-policy response, OECD Policy Responses to Coronavirus (COVID-19), <http://www.oecd.org/coronavirus/policyresponses/supporting-people-and-companies-to-deal-with-the-covid-19-virusoptions-for-an-immediate-employment-and-social-policy-response-d33dffe6/> .

Ozimek, A. (2020). The Future of Remote Work, Upwork. 
Palumbo, R. (2020). Let me go to the office! An investigation into the side effects of working from home on work-life balance. International Journal of Public Sector Management, 33(6-7), 771-790. https://doi.org/10.1108/IJPSM-06-2020-0150.

Rožman, M., \& Tominc, P. (2021). The physical, emotional and behavioral symptoms of health problems among employees before and during the COVID-19 epidemic. Employee Relations. https://doi.org/10.1108/ER-10-2020-0469.

Tagliaro, C., \& Migliore, A. (2021). "Covid-working": what to keep and what to leave? Evidence from an Italian company. Journal of Corporate Real Estate. https://doi.org/10.1108/JCRE-10-2020-0053.

Vanessa K. Bohns, \& Laura M. Giurge. (2020). 3 Tips to Avoid WFH Burnout. Harvard Business Review <https://hbr.org/2020/04/3-tips-to-avoid-wfh-burnout>

Zikmund W. G., Babin, B. J., Carr, J. C., Griffin, M. (2017). Business Research Methods. South-Wester, Cengage Learning. 